\title{
Burns associated with e-cigarette batteries: A case series and literature review
}

\author{
Jamie Harshman, $\mathrm{MD}^{*}{ }^{\dagger}$; Miliana Vojvodic, MSc, MD; Alan D. Rogers, MBChB, MMed*
}

\section{ABSTRACT}

Electronic cigarettes, often referred to as e-cigarettes, have established a considerable market in North America over the last decade. In parallel to this trend, there has been a surge of e-cigarette battery explosions reported in the general media. Given the growing number of such events, acute care physicians should recognize the associated risks and injury patterns and initiate appropriate treatment. This report presents two cases of burn injuries from e-cigarette battery explosions requiring surgical management. The accompanying comprehensive literature review highlights the emerging importance of e-cigarettes as an aetiology of burn injury.

\section{RÉSUMÉ}

Les cigarettes électroniques ont gagné une place considérable sur le marché, en Amérique du Nord, au cours de la dernière décennie. Parallèlement à la tendance, il s'est produit une hausse importante du nombre d'explosions de piles, signalées dans les médias généralistes. Compte tenu du nombre croissant de pareils événements, les médecins en soins actifs devraient être informés des risques associés à ces explosions et des types de blessures qui en découlent, et appliquer le traitement approprié. L'article expose deux cas de brûlures causées par des explosions de piles de cigarette électronique, qui ont nécessité une intervention chirurgicale. L'examen exhaustif de la documentation qui accompagne cet exposé met en évidence l'importance croissante des cigarettes électroniques comme cause de brûlure.

Keywords: burns, e-cigarettes, lithium ion battery, vaping

\section{INTRODUCTION}

As of 2014, the e-cigarette industry in North America reported revenues of $\$ 1.5$ billion, compared to just \$20 million in 2008. ${ }^{1}$ In Canada, 9\% of adults have smoked e-cigarettes at least once in the last 5 years, and use is expected to rise further. ${ }^{2}$ Despite the marketing of electronic cigarettes as safer, smoke-free counterparts to regular cigarettes, new consumer risks are being recognized and reported. Explosions of lithium ion batteries have been well documented in relation to their use in laptop computers and cellular phones. ${ }^{3-5}$ The electrolyte liquid within the lithium ion battery cells is at risk for overheating, thus building pressure that may exceed the capacity of the battery casing. This "thermal runway" can ultimately result in cell rupture or combustion. ${ }^{3,6}$

The purpose of this publication is to review e-cigarette battery explosions as an emerging aetiology of burn injury and to describe two cases requiring admission to an American Burn Association verified regional burn centre.

\section{CASE REPORT I}

A 31-year-old, previously healthy male was driving a motor vehicle when an e-cigarette battery ignited spontaneously in the pocket of his pants. The battery had been placed with several coins in the pocket. $\mathrm{He}$ was able to steer safely off of the road, remove his pants, and extinguish the flames with his hands. He was transported directly from the scene to the regional burn centre by Emergency Medical Services.

The patient sustained mixed partial thickness and full-thickness flame burns to his right anterolateral thigh, buttock and leg, as well as his left inner thigh (Figure 1, A and B). These findings were consistent on reassessment of possible progression after 24 hours. The total body surface area (TBSA) of the burn injury was calculated to be $10 \%$, according to the Lund and Browder chart. The burn wounds were thoroughly irrigated with water on presentation to remove debris and to cool the burned surface area. The patient was sedated with ketamine, fentanyl, and midazolam during this procedure. The thigh wounds were dressed with silver sulfadiazine cream in sterile gauze and wrapped

From the *Ross Tilley Burn Centre, Sunnybrook Health Sciences Centre, Toronto, ON; †Departments of Family and Community Medicine; and ¥Surgery, Division of Plastic and Reconstructive Surgery, University of Toronto, Toronto, ON.

Correspondence to: Dr. Jamie Harshman, University of Toronto, 603 Huron St., Toronto, ON M5R 2R8; Email: jamie.e.harshman@gmail.com 
with cling. He received a tetanus vaccination. His burns were debrided and successfully covered with autologous split thickness skin grafts on Day 3 of a 7-day
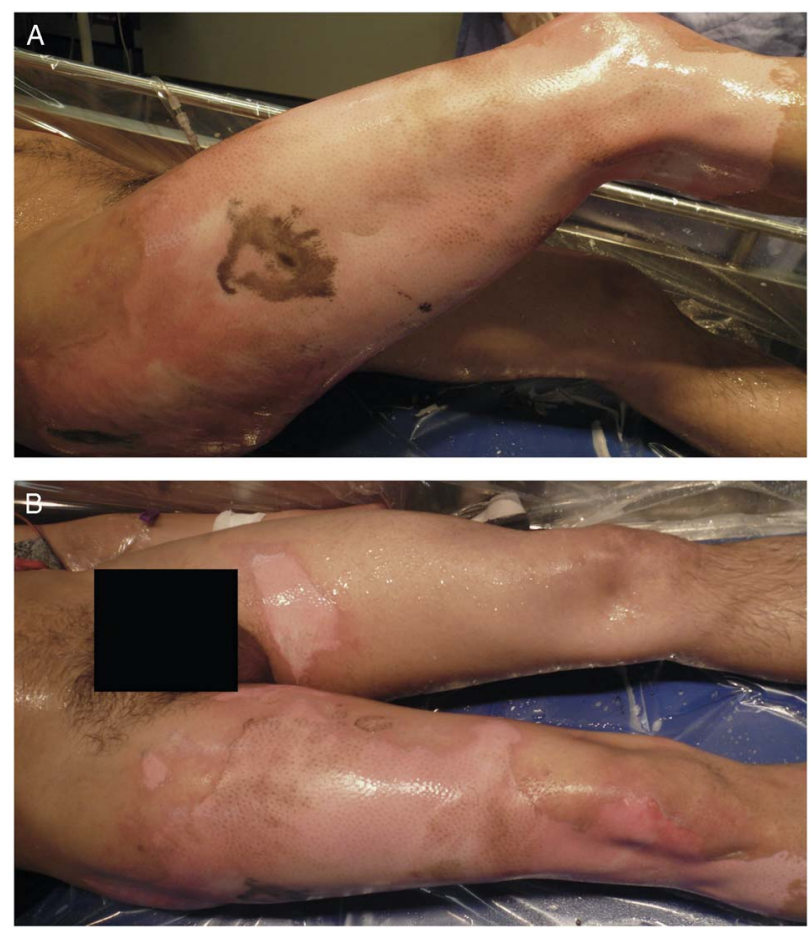

Figure 1. A) Right buttock and thigh burns of the patient in Case I. B) Bilateral anterior thigh burns in the patient in Case I, on the day of the burn injury.

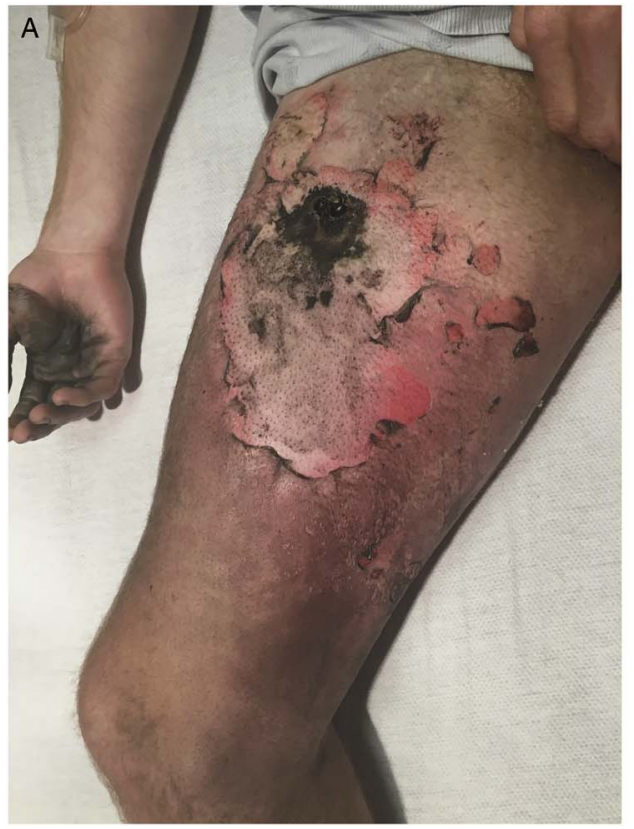

admission. The patient's pain was adequately controlled with oral hydromorphone, ibuprofen, and acetaminophen, and supplemented by intravenous hydromorphone or fentanyl postoperatively and for dressing changes. Gabapentin was added as an analgesic adjunct postoperatively, to address neuropathic pain after skin grafts were harvested. His postoperative recovery was uneventful. He received outpatient physiotherapy and recovered full function within 2 months.

\section{CASE REPORT II}

A 36-year-old previously healthy male had been storing an e-cigarette battery in the pocket of his pants along with several coins and keys. The patient was not aware that lithium ion batteries carried any risk of explosion. He recalls hearing a sound like a sparkler or firework when the battery spontaneously ignited and engulfed his pants in flame. He put the flames out with his hands and by dousing his pants with water. The patient was initially taken to a community hospital by Emergency Medical Services before a same day transfer to the regional burn centre for further management.

The patient sustained deep partial and full thickness burns to his right anteromedial thigh and superficial partial thickness burns to his right hand, cumulating in $3 \%$ TBSA (Figure 2, A). Part of the battery case was

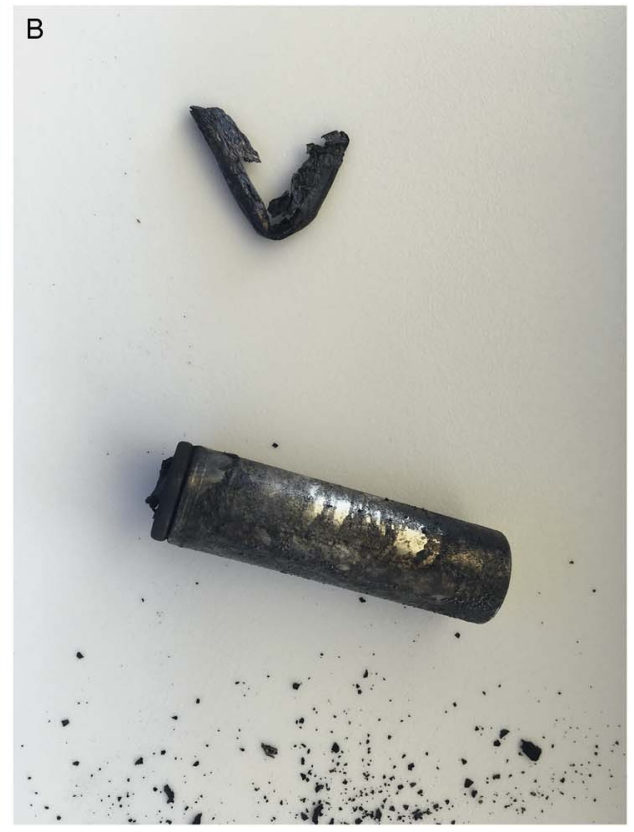

Figure 2. A) Anterior right thigh burn of the patient in Case II on the day of the burn injury. B) E-cigarette battery device and fragment of the casing removed from the thigh of the patient. 
embedded in his thigh and was removed at the burn centre on arrival (Figure 2, B). The wounds were thoroughly irrigated with sterile water and dressed with silver sulfadiazine cream in sterile gauze. Two days following the injury, the patient was noted to have developed cellulitis of the burn wounds, manifesting as tachycardia and a low-grade fever. He was treated with a course of cefazolin. His wounds were debrided on the third day following the injury. The underlying deep tissue injury necessitated excision of deep fascia overlying part of the sartorius and rectus femoris muscles. Due to the extent of the injury and the presence of burn wound infection, the wound was closed in two stages. Meshed, deceased donor allograft skin and negative pressure wound therapy were used to cover the wound in the first surgery. At the second operation, the allograft was found to be adherent, and no further debridement was deemed necessary. Meshed autograft was used to definitively close the wound, again bolstered by negative pressure wound therapy to optimize graft take. The patient required a 12-day hospital stay and returned to full function within 2 months of his injuries. He continues to be followed in the outpatient setting for scar management and uses pressure garments.

\section{REVIEW OF LITERATURE AND MEDIA REPORTS}

An electronic search was conducted using the MEDLINE database in May 2016. Search terms included "e-cigarette" AND "injury" OR "burn" OR "explosion" OR "trauma," "vaping and burn," "vaping and injury," and "cigarette and battery and burn." Articles were excluded for lack of relevance or for descriptions of chronic health effects of e-cigarettes rather than burns or explosions. Sixteen cases of spontaneous e-cigarette or e-cigarette battery ignition were retrieved. The Google search engine was used to identify news media reports of accidental e-cigarette or e-cigarette battery ignitions from 2015 to 2016 using the same terms listed previously. The media search was initially conducted in May 2016 and updated in June 2016.

The academic literature review yielded four case reports, two case series, and one published abstract describing injuries sustained from overheating or explosion of an e-cigarette device (Table 1). Six incidents involved isolated explosions of a lithium ion battery, similar to the cases presented in this series. Three e-cigarette devices exploded while in use, and one device exploded while not in use.
There has been a sharp increase in the number of e-cigarette-related reports in the literature (Figure 3). All reports involving explosion of e-cigarette batteries resulted in burn injuries, primarily to the lower extremities and hands. When reported, the extent of the burn injuries ranged from $1 \%$ to $8 \%$ TBSA and most commonly involved the lower extremity, hands, head and neck, and genitalia. Burn depth was predominantly deep partial and full thickness. In keeping with the depth of the injuries, at least $50 \%$ required surgical management of the burn wound. This report features a burn injury involving $10 \%$ TBSA, which at the time of writing is the most extensive burn resulting from an e-cigarette battery explosion published to date.

A search of general public media reports revealed 35 burns and associated injuries related to e-cigarette explosions between January 2015 and May 2016 (Table 2). Remarkably, over $60 \%$ of these incidents occurred in 2016 alone (see Figure 3).

The U.S. Federal Emergency Management Agency (FEMA) published a report in October 2014 documenting all media reports of e-cigarette battery explosions from 2009 to 2014. The search revealed 25 cases, resulting in 9 injuries, including 2 serious burns. ${ }^{3}$ The U.S. National Fire Protection Association (NFPA) published the only other review of incidents related to e-cigarette explosions in April 2016. From January to December 2015, a total of 15 cases of burns and/or explosions related to e-cigarettes were found, with 12 incidents involving injuries to a person. ${ }^{1}$ Our media search yielded 22 additional cases between January and June 2016. Although growing media attention may account for some of this upsurge in reports, the rising popularity of e-cigarettes is almost certainly contributory.

\section{DISCUSSION}

As more cases are reported, the spectrum of injury following e-cigarette battery explosions will be better delineated, thus allowing for targeted management approaches. The most frequent sites of injury observed with e-cigarette battery burns involve the lower extremities and hands. Nearly half of the reported incidences, including the two cases reported herein, required surgical management as a result of the depth of injury. Burns are typically less than 10\% TBSA and therefore do not meet the threshold for formal fluid resuscitation. As with all burns, acute care physicians should follow the Advanced Trauma Life Support 


\section{Table 1. Academic reports e-cigarette explosions, 2015-2016}

\begin{tabular}{|c|c|c|c|c|c|c|}
\hline Authors & Publication date & Involved body areas & Depth/size of burns & Other injuries & Interventions & Trigger \\
\hline $\begin{array}{l}\text { Shastry S, Langdorf M. } \\
\text { Electronic. J Emerg Med } \\
\text { 2016;17(2):177-80. }\end{array}$ & January 2013 & Chest, abdomen & $\begin{array}{l}\text { Partial thickness burn v. } \\
\text { foreign body penetration } \\
\text { upper chest and upper } \\
\text { abdomen }\end{array}$ & $\begin{array}{l}\text { Soft tissue wounds } \\
\text { from shrapnel }\end{array}$ & Routine wound care & $\begin{array}{l}\text { E-cigarette device } \\
\text { exploded during use }\end{array}$ \\
\hline $\begin{array}{l}\text { Jablow LM, Sexton RJ. } \\
\text { Am J Case Rep 2015; } \\
\text { 3(4):93-4. }\end{array}$ & February 2015 & Thigh, leg & $\begin{array}{l}8 \% \text { TBSA; partial thickness } \\
\text { burns to right thigh and } \\
\text { circumferential partial } \\
\text { thickness to right knee }\end{array}$ & - & $\begin{array}{l}\text { Unknown (transferred } \\
\text { to burn centre) }\end{array}$ & $\begin{array}{l}\text { Lithium battery } \\
\text { combustion }\end{array}$ \\
\hline $\begin{array}{l}\text { Walsh et al. BMJ Case } \\
\text { Rep 2016; Epub } 2016 \\
\text { March 9. }{ }^{9}\end{array}$ & February 2016 & Thigh & $\begin{array}{l}1.5 \% \text { mixed depth burn to } \\
\text { lateral right thigh }\end{array}$ & - & $\begin{array}{l}\text { Conservative } \\
\text { dressings }\end{array}$ & $\begin{array}{l}\text { Lithium battery } \\
\text { combustion }\end{array}$ \\
\hline $\begin{array}{l}\text { Colaianni et al. Eplasty } \\
\text { 2016;16:ic9. }{ }^{10}\end{array}$ & February 2016 & Thigh, genitalia, hands & $\begin{array}{l}\text { Full thickness burns to legs } \\
\text { and partial thickness burns } \\
\text { to genitalia and hands }\end{array}$ & - & $\begin{array}{l}\text { Debridement and } \\
\text { grafting }\end{array}$ & $\begin{array}{l}\text { Explosion of lithium } \\
\text { battery }\end{array}$ \\
\hline $\begin{array}{l}\text { Colaianni et al. Eplasty } \\
\text { 2016;16:ic9. }{ }^{10}\end{array}$ & February 2016 & Thigh, genitalia, hands & $\begin{array}{l}\text { Full thickness burns to legs } \\
\text { and partial thickness burns } \\
\text { to genitalia and hands }\end{array}$ & - & $\begin{array}{l}\text { Debridement and } \\
\text { grafting }\end{array}$ & $\begin{array}{l}\text { Explosion of lithium } \\
\text { battery }\end{array}$ \\
\hline $\begin{array}{l}\text { Colaianni et al. Eplasty } \\
\text { 2016;16:ic9.10 }\end{array}$ & February 2016 & Face & - & $\begin{array}{l}\text { Facial lacerations and } \\
\text { tooth fractures }\end{array}$ & $\begin{array}{l}\text { Intubation, laceration } \\
\text { repair }\end{array}$ & $\begin{array}{l}\text { E-cigarette device } \\
\text { exploded during use }\end{array}$ \\
\hline $\begin{array}{l}\text { Nicoll et al. Burns 2016; } \\
\text { 42(4):e42-6. }{ }^{11}\end{array}$ & April 2016 & Thigh, hand & $\begin{array}{l}\text { 4\% TBSA superficial partial } \\
\text { thickness to thigh; } \\
\text { superficial burns to right } \\
\text { hand }\end{array}$ & & $\begin{array}{l}\text { Conservative care, } \\
\text { wound dressings }\end{array}$ & $\begin{array}{l}\text { Lithium battery } \\
\text { combustion }\end{array}$ \\
\hline $\begin{array}{l}\text { Nicoll et al. Burns 2016; } \\
\text { 42(4):e42-6. }{ }^{11}\end{array}$ & April 2016 & Thigh, hand & $\begin{array}{l}\text { 3\% TBSA superficial partial } \\
\text { thickness to thigh; } \\
\text { superficial burns to right } \\
\text { hand }\end{array}$ & & $\begin{array}{l}\text { Conservative care, } \\
\text { wound dressings }\end{array}$ & $\begin{array}{l}\text { Lithium battery } \\
\text { combustion }\end{array}$ \\
\hline $\begin{array}{l}\text { Patterson et al. J Burn } \\
\text { Care Res 2016;37 } \\
\text { (Suppl 1):S247. }{ }^{12}\end{array}$ & May 2016 & Thigh, genitals, hand & $1 \%$ TBSA burn & - & $\begin{array}{l}\text { Burn debridement and } \\
\text { grafting to thigh; } \\
\text { circumcision }\end{array}$ & Device explosion \\
\hline $\begin{array}{l}\text { Roger et al. J Oral } \\
\text { Maxillofac Surg 2016; } \\
\text { 74(6):1181-5. }{ }^{.13}\end{array}$ & June 2016 & Abdomen, head/face & $\begin{array}{l}\text { Abdominal burns, details not } \\
\text { disclosed }\end{array}$ & $\begin{array}{l}\text { Oral soft tissue injury, } \\
\text { tooth fracture, tooth } \\
\text { avulsions }\end{array}$ & $\begin{array}{l}\text { Laceration repair, oral } \\
\text { surgery }\end{array}$ & $\begin{array}{l}\text { E-cigarette device } \\
\text { exploded during use }\end{array}$ \\
\hline
\end{tabular}




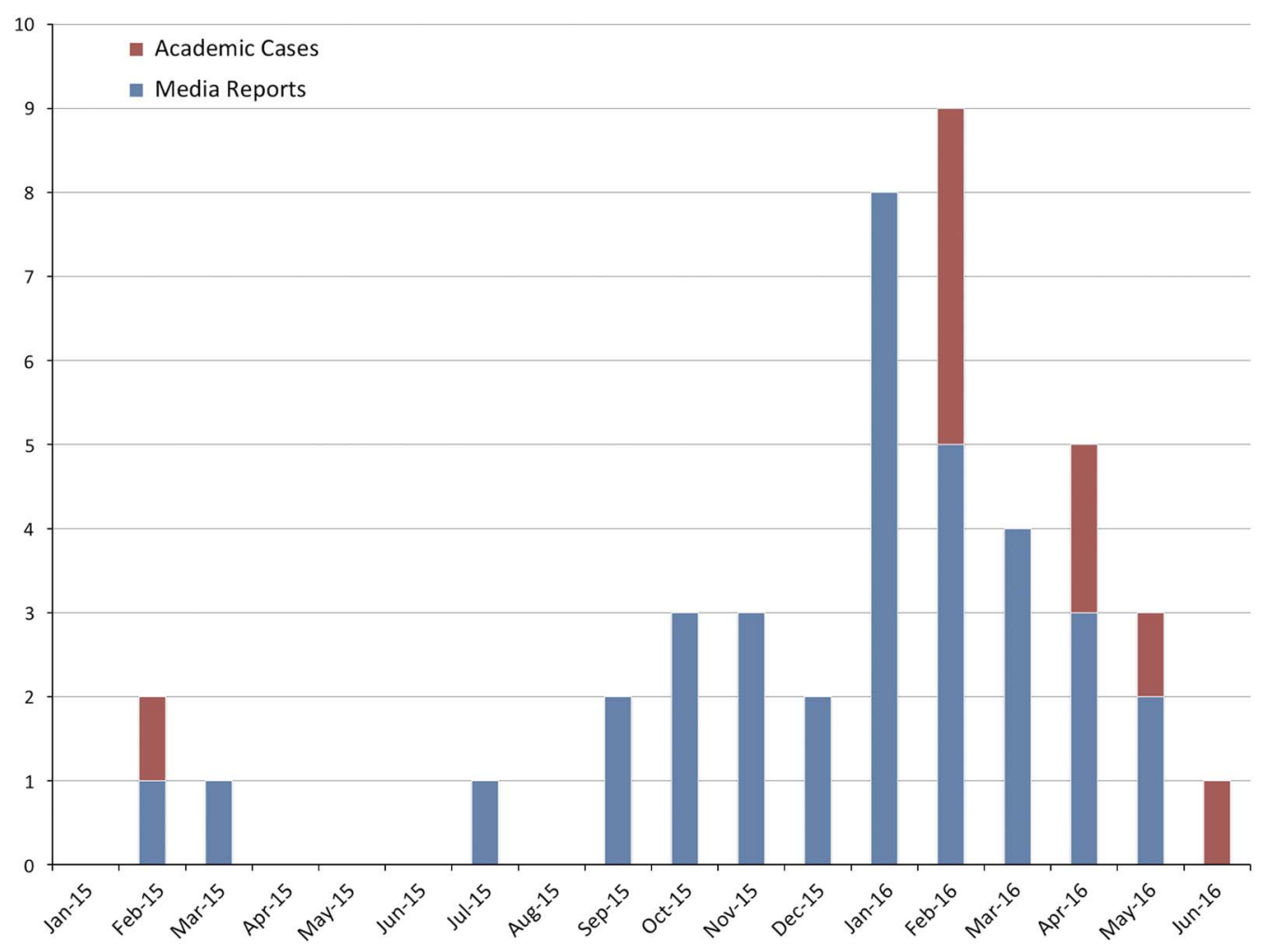

Figure 3. Incidence, by media and academic reports, of e-cigarette explosion-related injuries, 2015-2016 (as of June 26, 2016).

guidelines on patient arrival. Important adjunctive treatments include cleaning and cooling all burned areas with water prior to application of a non-adherent dressing. Importantly, burns to the hand, the genitalia, the face, chemical burns, and deep burns require a consultation with a burn surgeon, as per the referral guidelines of the American Burn Association.

First aid for exposure to the contents of lithium ion batteries includes a thorough irrigation of the affected site with water. ${ }^{40}$ Rechargeable lithium ion batteries do not contain lithium metal and thus the use of water is safe and appropriate. ${ }^{41-42}$ Nonetheless, medical staff should always don appropriate personal protective equipment because the other components of lithium ion batteries may cause skin or eye irritation. In addition to flame burns, a recent case report by Nicoll et al. ${ }^{5}$ discusses a patient who presented with features of both flame and alkali burns. The authors verified the alkali component of the burn through skin $\mathrm{pH}$ testing. ${ }^{11}$ With suspicion of a chemical or mixed burn pattern, acute care physicians are urged to contact the regional burn centre for early, specialized management.

Metal objects, such as coins or keys, can create a short circuit when stored with batteries, which initiates battery overheating. ${ }^{43}$ Khundkar et al. ${ }^{43}$ presented a report where loose change in the pocket of their patient created a short circuit by connecting the positive and negative electrodes of a non-rechargeable battery. Walsh et al. ${ }^{9}$ also reported a case where an e-cigarette battery stored with keys ignited in a patient's pocket, resulting in a mixed depth burn of the thigh.

The regulatory landscape for e-cigarette sales in Canada lags behind their rapid spread of use. At present, if an e-cigarette device or liquid contains nicotine or makes a health claim, they fall under the Food and Drugs Act. Because Health Canada has not yet approved e-cigarettes as delivery vehicles for nicotine, they are illegal to sell in Canada. ${ }^{2}$ Regardless, both nicotine and non-nicotine containing e-cigarette products are widely available for purchase in Canada. Manufacturing guidelines established by the United Nations require lithium ion batteries and battery components to be tested to meet specific safety criteria, but batteries purchased through unreliable distributors or manufacturers of counterfeit products may not meet these guidelines and are thus at greater risk of igniting or exploding. ${ }^{42}$ Without regulation or control of the sale of these products, consumers must rely on safety advice that they 


\begin{tabular}{|c|c|c|c|c|c|c|c|}
\hline \multirow{4}{*}{ 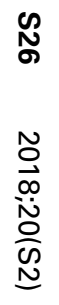 } & \multicolumn{7}{|c|}{ Table 2. (Continued) } \\
\hline & $\begin{array}{l}\text { Date of } \\
\text { incident }\end{array}$ & Source & $\begin{array}{l}\text { Involved body } \\
\text { areas }\end{array}$ & Depth/size of burns & Other injuries & Treatment & Trigger \\
\hline & $\begin{array}{l}\text { January } \\
2016^{28}\end{array}$ & Mirror & $\begin{array}{l}\text { Head/face, } \\
\text { hand }\end{array}$ & Facial and hand burns & Dental trauma & Debridement and grafting & $\begin{array}{l}\text { Device combustion while using } \\
\text { e-cigarette }\end{array}$ \\
\hline & $\begin{array}{l}\text { January } \\
2016^{27}\end{array}$ & Daily Mail & Head/face & - & $\begin{array}{l}\text { Ocular trauma and facial } \\
\text { laceration }\end{array}$ & Surgical repair, eye & $\begin{array}{l}\text { Device combustion while using } \\
\text { e-cigarette }\end{array}$ \\
\hline \multirow{15}{*}{ 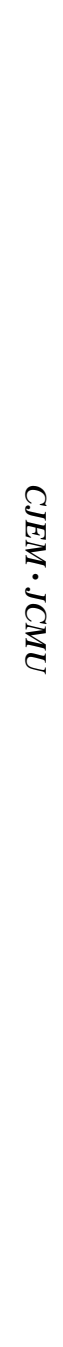 } & $\begin{array}{l}\text { January } \\
2016^{29}\end{array}$ & $\mathrm{BBC}$ & $\begin{array}{l}\text { Head/face, } \\
\text { neck, } \\
\text { forearm }\end{array}$ & Burns to face, neck, wrist & Dental trauma & Unknown & $\begin{array}{l}\text { Device combustion while using } \\
\text { e-cigarette }\end{array}$ \\
\hline & $\begin{array}{r}\text { February } \\
2016^{18}\end{array}$ & $\begin{array}{l}\text { Seattle } \\
\text { Times }\end{array}$ & $\begin{array}{l}\text { Head/face, } \\
\text { hand }\end{array}$ & Second degree burn & - & Unknown & $\begin{array}{l}\text { Device combustion while using } \\
\text { e-cigarette }\end{array}$ \\
\hline & $\begin{array}{r}\text { February } \\
2016^{30}\end{array}$ & CNN & Thigh & Partial thickness burns & - & Unknown & Lithium battery combustion \\
\hline & $\begin{array}{r}\text { February } \\
2016^{31}\end{array}$ & $\begin{array}{l}\text { Fox } 13 \\
\text { News }\end{array}$ & $\begin{array}{l}\text { Thigh/leg, } \\
\text { hand }\end{array}$ & Partial thickness burns & - & Unknown & $\begin{array}{l}\text { Lithium battery combustion, stored } \\
\text { with coins in pants pocket }\end{array}$ \\
\hline & $\begin{array}{r}\text { February } \\
2016^{32}\end{array}$ & $\begin{array}{l}\text { NY Daily } \\
\text { News }\end{array}$ & Thigh & Partial thickness burns & - & Unknown & Lithium battery combustion \\
\hline & $\begin{array}{r}\text { February } \\
2016^{33}\end{array}$ & $\begin{array}{l}\text { Fox } 13 \\
\text { News }\end{array}$ & Thigh/leg & $\begin{array}{l}\text { Mixed depth burns, including } \\
\text { partial and full thickness }\end{array}$ & - & Unknown & $\begin{array}{l}\text { Combustion of e-cigarette and charger } \\
\text { unit }\end{array}$ \\
\hline & $\begin{array}{l}\text { March } \\
2016^{34}\end{array}$ & $\begin{array}{l}\text { CBS New } \\
\text { York }\end{array}$ & Head/face & - & $\begin{array}{l}\text { Facial and ocular trauma, } \\
\text { visual impairment }\end{array}$ & Unknown & $\begin{array}{l}\text { Device combustion while using } \\
\text { e-cigarette }\end{array}$ \\
\hline & $\begin{array}{l}\text { March } \\
2016^{35}\end{array}$ & $\begin{array}{l}\text { Pittsburgh } \\
\text { Post- } \\
\text { Gazette }\end{array}$ & $\begin{array}{l}\text { Thigh, } \\
\text { genitals }\end{array}$ & Partial and full thickness burns & - & Debridement and grafting & $\begin{array}{l}\text { Lithium battery combustion, contact } \\
\text { with keys or coins in pants pocket }\end{array}$ \\
\hline & $\begin{array}{l}\text { March } \\
2016^{35}\end{array}$ & $\begin{array}{l}\text { Pittsburgh } \\
\text { Post- } \\
\text { Gazette }\end{array}$ & Thigh & Partial and full thickness burns & - & Debridement and grafting & $\begin{array}{l}\text { Lithium battery combustion, contact } \\
\text { with keys or coins in pants pocket }\end{array}$ \\
\hline & $\begin{array}{l}\text { March } \\
2016^{35}\end{array}$ & $\begin{array}{l}\text { Pittsburgh } \\
\text { Post- } \\
\text { Gazette }\end{array}$ & Hand & Partial and full thickness burns & - & Unknown & $\begin{array}{l}\text { Lithium battery combustion, contact } \\
\text { with keys or coins in pants pocket }\end{array}$ \\
\hline & $\begin{array}{l}\text { April } \\
2016^{36}\end{array}$ & AJC News & Thigh/leg & Partial and full thickness burns & - & Unknown & Lithium battery combustion \\
\hline & $\begin{array}{l}\text { April } \\
2016^{37}\end{array}$ & $\begin{array}{l}\text { Global } \\
\text { News }\end{array}$ & Head/face & - & $\begin{array}{l}\text { Facial fracture, ocular } \\
\text { trauma, and vision } \\
\text { impairment }\end{array}$ & Surgical repair of facial fractures & $\begin{array}{l}\text { Device combustion while using } \\
\text { e-cigarette }\end{array}$ \\
\hline & $\begin{array}{l}\text { April } \\
2016^{38}\end{array}$ & $\begin{array}{r}\text { Daily News } \\
\text { New York }\end{array}$ & Thigh/leg & Full thickness burns & - & Debridement and grafting & Lithium battery combustion \\
\hline & May $2016^{39}$ & Fox 2 Now & Thigh & Full thickness burns & - & Debridement and grafting & Lithium battery combustion \\
\hline & May $2016^{39}$ & Fox 2 Now & Thigh & Full thickness burns & - & Unknown & Lithium battery combustion \\
\hline
\end{tabular}


receive at the point of sale or on the Internet, which is inconsistent at best. Furthermore, given the lack of a user manual and product labeling regulations for e-cigarettes, consumers are often unaware of the risks of improper lithium ion battery storage or charging.

\section{CONCLUSION}

As e-cigarette use continues to rise in popularity, burns resulting from e-cigarette battery explosions will become a more prevalent presentation in the acute care setting. For acute care physicians, the recognition of these injuries is paramount in initiating an appropriate management algorithm, which often includes referral to a regional burn centre. This case series and literature review highlight the need for improved regulation of e-cigarette devices and advocate for clear warnings on product labels, to make e-cigarette users aware of the risks of battery explosion.

\section{Competing interests: None declared.}

\section{REFERENCES}

1. Campbell R. National Fire Protection Association, Fire Analysis and Research Division. Electronic cigarette explosions and fires: the 2015 experience; 2016.

2. Czoli CD, Reid JL, Rynard VL, et al. E-cigarettes in Canada tobacco use in Canada: patterns and trends, 2015 edition, special supplement. Waterloo, ON: Propel Centre for Population Health Impact, University of Waterloo; 2015.

3. U.S. Fire Administration, FEMA, U.S. Department of Homeland Security. Electronic cigarette fires and explosions; 2014. Available at: https://www.usfa.fema.gov/downloads/pdf/ publications/electronic_cigarettes.pdf (accessed 25 June 2016).

4. Rose A, Hassan Z, Falder S. Lithium-ion battery: the "mini-bomb" in your pocket, on your desk, and behind your wheels. 7 Burn Care Res 2010;31(4):675.

5. Mankowski PJ, Kanevsky J, Bakirtzian P, et al. Cellular phone collateral damage: a review of burns associated with lithium battery powered mobile devices. Burns 2016;42(4):e61-4.

6. Ebbert J, Agunwamba A, Rutten L. Counseling patients on the use of electronic cigarettes. Mayo Clin Proc 2015;90 (1):128-34.

7. Shastry S, Langdorf $M$. Electronic vapor cigarette battery explosion causing shotgun-like superficial wounds and contusion. 7 Emerg Med 2016;17(2):177-80.

8. Jablow LM, Sexton RJ. Spontaneous electronic cigarette explosion: a case report. Am 7 Case Rep 2015;3(4):93-4.

9. Walsh K, Sheikh Z, Johal K, et al. Rare case of accidental fire and burns caused by e-cigarette batteries. BM7 Case Rep 2016; epub, doi:10.1136/bcr-2015-212868.

10. Colaianni CA, Tapias LF, Cauley R, et al. Injuries caused by explosion of electronic cigarette devices. Eplasty 2016;16:ic9.
11. Nicoll KJ, Rose AM, Khan MAA, et al. Thigh burns from exploding e-cigarette lithium ion batteries: first case series. Burns 2016;42(4):e42-6.

12. Patterson SB, Beckett A, Lintner A, et al. E-cigarette explosions in the USA: a case report and classification of injuries from the literature [abstract]. $\mathcal{F}$ Burn Care Res 2016;37(Suppl 1):S247.

13. Roger J, Abayon M, Elad S, et al. Oral trauma and tooth avulsion following explosion of e-cigarette. 7 Oral Maxillofac Surg 2016;74(6):1181-5.

14. Boyle D. Former LA Galaxy star suffers hole in his cheek after an e-cigarette exploded in his face. Daily Mail Online; 2015. Available at: http://www.dailymail.co.uk/news/article-3327374/ Former-LA-Galaxy-star-suffers-hole-cheek-e-cigarette-explodedface-industry-faces-string-lawsuits-victims-say-suffered-burnslost-FINGERS.html (accessed 26 June 2016).

15. Lee G. E-cigarette lodges into ceiling after exploding in Santa Ana's man's hands. ABC Los Angeles; 2015. Available at: http:// abc7.com/news/e-cigarette-lodges-into-ceiling-after-explodingin-oc-mans-hands/551894/ (accessed 26 June 2016).

16. Roman J. Man seriously injured after e-cigarette explodes in his face. Tech Times; 2015. Available at: http://www.techtimes. com/articles/86104/20150919/man-seriously-injured-after-ecigarette-explodes-in-his-face.htm (accessed 26 June 2016).

17. Mojica A. Tenn teen burned by exploding vape warns of potential dangers. Fox 17 News; 2016. Available at: http://fox17.com/news/local/white-house-teen-burned-byexploding-vape-warns-of-potential-dangers (accessed 26 June 2016).

18. Aleccia J. E-cigarettes are exploding in vapers' mouths leaving gruesome injuries. The Seattle Times; 2016. Available at: http://www.seattletimes.com/seattle-news/health/explodinge-cigarettes-send-vapers-to-harborview-with-gruesome-injuries/ (accessed 26 June 2016).

19. Florida man placed in coma after e-cigarette explosion. Fox News; 2015. Available at: http://www.foxnews.com/health/ 2015/10/28/florida-man-placed-in-coma-after-e-cigaretteexplosion.html (accessed 26 June 2016).

20. Whaley M. Colorado vapers burned by exploding e-cigarettes. The Denver Post; 2016. Available at: http://www.denverpost. com/2016/01/29/colorado-vapers-burned-by-explodinge-cigarettes/ (accessed 26 June 2016).

21. Gastaldo E. E-cigarette explodes as guy tries to smoke it. Newser; 2015. Available at: http://www.newser.com/story/ 215866/e-cigarette-explodes-as-guy-tries-to-smoke-it.html (accessed 26 June 2016).

22. Carter B. "I'd rather have lung cancer": e-cigarette battery explodes in man's pocket. Fox 17 News; 2015. Available at: http://fox17online.com/2015/12/08/id-rather-have-lungcancer-e-cigarette-explodes-in-mans-pocket/ (accessed 26 June 2016).

23. Shanahan K. "Blood just pouring down," e-cig explodes in Oklahoma man's face. KFOR News; 2015. Available at: http:// kfor.com/2015/12/08/blood-just-pouring-down-e-cig-explodesin-oklahoma-mans-face/ (accessed 26 June 2016).

24. Chen T. E-cigarette lawsuit claims battery explosion caused third-degree burns. NBC Southern California; 2016. Available at: http://www.nbclosangeles.com/news/local/ e-cigarette-explode-lawsuit-battery-los-angeles.html (accessed 26 June 2016). 
25. New Hampshire man burned when vaporizer battery explodes. WCVB Boston; 2016. Available at: http://www. wcrb.com/news/new-hampshire-man-burned-when-vaporizerbattery-explodes/37635998 (accessed 26 June 2016).

26. Cotter J. Exploding e-cigarette "lit my kid's face on fire," warns Alberta father. CBC Calgary; 2016. Available at: http://www. cbc.ca/news/canada/calgary/alberta-father-calls-for-ban-one-cigarettes-1.3423099 (accessed 26 June 2016).

27. Malm S. Man's teeth are blown out when e-cigarette explodes in his mouth, causing serious facial injuries. Daily Mail Online; 2016. Available at: http://www.dailymail. co.uk/news/article-3422612/Man-s-teeth-blown-e-cigaretteexplodes-mouth-causing-facial-injuries.html (accessed 26 June 2016).

28. Hill P. E-cigarette exploded in man's mouth "like dynamite" as fire services demand urgent action. Mirror; 2016. Available at: http://www.mirror.co.uk/news/uk-news/ e-cigarette-exploded-mans-mouth-7325156 (accessed 26 June 2016).

29. E-cigarette explodes in man's mouth in Telford. BBC News; 2016. Available at: http://www.bbc.com/news/uk-englandshropshire-35364420 (accessed 26 June 2016).

30. Goldschmidt D. Man says e-cigarette battery exploded in his pocket. CNN; 2016. Available at: http://www.cnn.com/ 2016/02/25/health/e-cigarette-explodes-in-mans-pocket/ (accessed 26 June 2016).

31. Nuñez K. Utah man burned by exploding battery urges other e-cigarette users to be cautious. Fox 13 News; 2016 Available at: http://fox13now.com/2016/02/19/utah-manburned-by-exploding-battery-urges-other-e-cigarette-usersto-be-cautious/ (accessed 26 June 2016).

32. Hanna L. British man scarred for life after e-cigarette battery explodes in his pocket. NY Daily News; 2016. Available at: http://www.nydailynews.com/news/world/ukman-scarred-life-e-cig-explodes-pocket-article-1.2537188 (accessed 26 June 2016).

33. McDonald $M$. Utah man says he suffered third-degree burns after e-cigarette exploded in his pocket. Fox 13 Salt Lake City; 2016. Available at: http://fox13now.com/2016/02/17/utah-mansays-he-suffered-third-degree-burns-after-e-cigarette-explodedin-his-pocket/ (accessed 26 June 2016).
34. Castro V. Teen badly injured when vape pen explodes at Brooklyn mall. CBS New York; 2016. Available at: http://new york.cbslocal.com/2016/04/14/vape-pen-explodes/ (accessed 26 June 2016).

35. Templeton D. Three men suffer serious burns from e-cigarette battery fires. Pittsburgh Post-Gazette; 2016. Available at: http:// www.post-gazette.com/local/region/2016/03/18/Three-mensuffer-serious-burns-from-e-cigarette-battery-fires/stories/ 201603170020 (accessed 26 June 2016).

36. Eldridge E. Fulton man seriously burned after e-cigarette battery explodes. AJC News; 2016. Available at: http://www. ajc.com/news/news/local/fulton-man-seriously-burned-after-ecigarette-batt/nrCRk/ (accessed 26 June 2016).

37. Maveal A. California man loses eye in e-cigarette explosion. Global News; 2016. Available at: http:/globalnews.ca/news/ 2694377/california-man-loses-eye-in-e-cigarette-explosion/ (accessed 26 June 2016).

38. Rayman G. E-cigarette violently explodes in pocket of Queens woman, 26, leaving her with severe burns and device's battery lodged in car dashboard. Daily News New York; 2016. Available at: http://www.nydailynews.com/new-york/ e-cigarette-violently-explodes-pocket-queens-woman-article1.2607505 (accessed 26 June 2016).

39. Faust V. E-cig users report severe burns after devices explode. Fox 2 Now; 2016. Available at: http://fox2now. com/2016/05/12/e-cig-users-report-severe-burns-after-devicesexplode/ (accessed 26 June 2016).

40. Rechargeable lithium-ion batteries, MSDS [Online]; 2005. Available at: https:/www.uscg.mil/hq/cg4/cg432/docs/msds/ MSDS_LiIon.pdf (accessed 9 November 2016).

41. International Air Transport Association. Lithium battery guidance document; 2016. Available at: https:/www.iata.org/ whatwedo/cargo/dgr/Documents/lithium-battery-guidancedocument-2016-en.pdf (accessed 9 November 2016).

42. Transport Canada. Transportation of dangerous goods: did you know that lithium batteries are dangerous goods? RDIMS No. 10277515; 2016. Available at: https://www.tc. gc.ca/eng/tdg/lithium-batteries-are-dangerous-goods-1162. html (accessed 9 November 2016).

43. Khundkar R, Malic C, Estela C. Burned by a battery-coin short circuit: old concept for a new burn. Burns 2010;36:e4-5. 